2

3

4

5

6

7

8

9

10

11

12

13

14

15

16

17

18

19

20

21

22

23

24

25

26

27

28

29

30

31

32

33

34

35

36

37

38

39

40

41

42

43

44

45

46

47

48

49

50

\title{
Bees support farming. Does farming support bees?
}

Preeti S. Virkar ${ }^{1 \mp *}$, Ekta Siddhu $^{2 \&}$, V. P. Uniyal ${ }^{3}$

${ }^{1}$ Department of Zoology, North Eastern Hill University, Shillong, Meghalaya, India

${ }^{2}$ PGT Biology, Oak Grove School, Dehradun, Uttarakhand, India

${ }^{3}$ Landscape Level Planning and Management, Wildlife Institute of India, Dehradun, India

* Corresponding author

E-mail: preetivirkar85@gmail.com

I This author contributed equally to the work

\& This author also contributed equally to the work

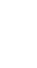

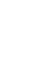

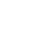

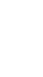


51

\section{Abstract}

Tropical regions are subjected to rapid land use changes altering species composition and diversity in communities. The non-Apis bees are vital invertebrates continued to be highly neglected in the tropics. We compared their diversity status, richness and composition across natural areas and agroecosystems in Doon valley, a subtropical-temperate landscape situated at the foothills of outer Himalayas in India. We investigated how two major habitats relate to non-Apis bee diversity, specifically seeking answers to (1) Whether natural habitat is a refuge to richer and rarer bee communities than agroecosystems? (2) Are natural habitats important for supporting wild bee populations in agroecosystems? (3) Do polyculture farms behave similar to natural habitats and therefore support richer bee communities than monoculture? Observation and pantrap sampling were used to collect data. We recorded 43 species belonging to bees of five families. The findings of our investigation demonstrate the importance of natural habitats as a potential refuge for non-Apis bees. The findings highlighted that Doon valley harboured twenty-five rare species of non-Apis bees, and natural habitats are a refuge to 11 rare specialist species (clamtest; Specialization threshold $\mathrm{K}=2 / 3$, Alpha level = 0.005). Natural habitat diversity in Doon valley supports bee communities in nearby agroecosystems $(\mathrm{R} 2=0.782, \mathrm{SE}=0.148, \mathrm{P}=0.004)$. Polyculture practices in agroecosystems $\left(<100 \mathrm{~m}\right.$ from forest $\mathrm{H}^{\prime}=2.15 ;>100 \mathrm{~m}$ from forest $\left.=2.08\right)$ in the valley mimic natural habitats $\left(\mathrm{H}^{\prime}=2.37\right)$ and support diverse non-Apis bee communities (2.08) in comparison to monocultures $\left(<100 \mathrm{~m}\right.$ from forest $\mathrm{H}^{\prime}=2.13 ;>100 \mathrm{~m}$ from forest $\left.=1.56\right)$. Bees evolved with flowering plants over 120 million years and they suffice an evergrowing anthropogenic nutrition needs with their services through enhanced agricultural production in pursuit of forage. We finally recommend similar assessments of bee diversity and plants they support in different habitats and vice versa. 


\section{Introduction}

Pollinators have a crucial role to play in pollination, a key ecological service, that enhances plant production $[1,2]$. Bees, in particular, are considered the prime pollinator group $[3,4]$. Beekeeping has hence become an indispensable part of farming cultures worldwide. Managed honey bees successfully pollinate and are responsible for the production of seeds and fruits of about $75 \%$ of the most commonly consumed food crops worldwide [5] and an unknown number of wild plants globally [1,2,5]. In addition to the managed honey bees, pollination by the native wild bees is an indiscernible but imperative process to the ecosystem. Native wild bees (non-Apis) other than honey bees (Apis) are increasingly finding the center stage in the backdrop of the global decline of the managed bees $[6,7]$. Over the last half a decade the honey bee populations suffered a massive decline globally, predominantly in North America [8,9] and a Europe [10,11], leading to pollinator crisis [12].

There are several reasons for the bee decline such as climate change $[13,14]$, pollution, pesticide usage $[15,16]$, introduction of exotic species $[17,18]$, electromagnetic waves from mobile towers [19], and pathogens, [20] etc. Changing climate and land use are among the prime drivers of pollinator decline degrading their habitats. Conversion of additional natural land for agriculture is a significant cause of pollinator habitat degradation [21]. It alters biodiversity [22,23], and is predicted to be one of the leading causes of species loss in the future owing to anthropogenic modifications in the global environment [24-26], particularly in the tropics. Tropical regions sustain rare and endemic species of plants, animals and their ecosystem services. Owing to lack of exploration and documentation, the discovery of many species may be yet remaining. There is limited baseline information on the status of non-Apis bees in the changing tropical and subtropical landscapes [27]. 

1990-2015) 129 million ha of natural land were lost to agriculture worldwide [31]. Tropical and developing countries such as India have undergone much rapid land cover conversions. From 1880-2010 the land use land cover (LULC) in India the forests cover decreased by $34 \%$ (134 million ha to 88 million ha) while the agricultural land increased by $52 \%$ (92 million ha to 140 million ha) [32]. Studies demonstrate that natural habitats are reservoirs of resources required by bees that may be absent in agroecosystems [7,3336]. Forest cover reduction and farmlands gaining vegetation uniformity with increasing monoculture cause the loss of nesting and foraging sites of the bee pollinators $[37,38]$. Studies on semi-natural habitats have shown to differentially support bee populations in agricultural landscapes $[39,40]$. Pollinators' utilize forest and agrarian habitats for resources such as forage and nesting [22,41-44]. Monoculture reduces not only natural areas [45] in and around farms but also the floral diversity [38]. The recent bee falloff is attributed to increased conventional monoculture agricultural practices that reduce wildflower abundance [16,46-49]. These practices upset the plant-pollinator community structure [14] and function [50]. Agricultural intensification is an critical global change

119 presently leading to local and global consequences such as poor biodiversity, soil 120 depletion, water pollution and eutrophication and atmospheric components [51]. It can negatively affect the insect pollination services, and thus, decreasing the production of $66 \%$ crops impacting the global nutrition supply [52]. In the wake of such information,

123 one wonders what kind of differences agriculture and natural habitat might bring to bee 124 diversity. 

gradually falling prey to alterations in climate and land cover, to support growing economic needs. These very causes are affecting bee populations worldwide as well, and the Himalayas are particularly sensitive to them [53-56]. Rising temperatures influence plant reproduction and phenology. Mismatch of the plant life cycle will, in turn, affect the pollinators [13,57-59]. Understanding the ecosystem services in the Himalayas has begun [60]. The Global Pollination Project, in particular, investigated the contribution of insect pollinators to the productivity of important crops such as oilseeds, fruits and spices cultivated in the Indian Himalayas [61].

Himalayan agriculture is dependent on the managed pollinators for crop productivity. A secondary economic source through honey production is an age-old practice in these mountains [62-65]. The introduction of the non-native honey bees, increasing anthropogenic pressures on the natural resources, climate and lifestyle alterations are further challenging the traditional beekeeping in the region. Few 139 investigations revealed honey bee declines reported in the Himalayan ecosystems [62,6568]. The rate of honey bee decline in the region and South Asia on a broader scale is 141 unknown. This gap points out the need for utilizing the services of non-Apis bees to

142 improve the reproduction in the wild and cultivated Himalayan plants. Lack of 143 comprehensive investigation and historical records on non-Apis bees is a hindrance 144 towards understanding their ecological function and economic potential in the region. 145 Doon valley is a mosaic of natural, agricultural and human habitats, situated at the 146 foothills of the outer Himalayas. Demonstrating both, traditional chemical-free temperate 147 mountain farming and the conventional intensive cultivation from the Gangetic plains, 148 this Himalayan valley is a perfect example of the changing Himalayan LULC. Few 149 studies in the recent past that have looked at the insect pollinators in Doon valley. Jiju et 
150

151

152

171 and perennial riverine systems, agriculture land and urban settlements (Fig 2 and Table

al [69] recorded pollinators and flower visitors viz. Dipterans $(\mathrm{n}=7)$, Hymenopterans (honey bees $n=3-$, wasp $n=1-)$, Coleopterans $(n=3)$, Hemipterans $(n=1)$ and Lepidopterans $(n=4)$ in an organic farm. This investigation, however, lacked any records of nonApis bees. Migrating human populations from the mountains and the plains are causing rapid land use alterations affecting diverse faunal species in the Doon valley (Yang et al. 2013). Transitionary climatic conditions and geography make the Doon valley a unique landscape ideal for supporting a potential source population of non-Apis bees for the surrounding areas. We investigate how two major habitats of LULC viz. natural and agriculture in the Doon valley landscape, affect non-Apis bee diversity, specifically seeking answers to (1) Whether natural habitat is a refuge to diverse and rarer bee communities than the agroecosystems? (2) Are natural habitats important for supporting wild bee populations in agroecosystems? (3) Do polyculture farms behave similarly to natural habitats, thus support species-rich and diverse bee communities than monoculture?

\section{Methods}

\section{Study Area}

Doon valley (latitudes $29^{\circ} 59^{\prime}$ to $30^{\circ} 30^{\prime} \mathrm{N}$ and longitudes $77^{\circ} 35^{\prime}$ to $78^{2} 24^{\prime}$ E) is situated in the western corner of Uttarakhand state, India (Fig 1). It is spread over approximately $1850 \mathrm{~km} 2$ area with the elevation ranging from $330 \mathrm{~m}$ to $800 \mathrm{~m}$ above mean sea-level. The valley is a mosaic of natural habitats such as forest patches, seasonal

172 1). Situated at the foothills of the Himalayas, the valley is sandwiched between the

173 Shivalik ranges. The rivers Ganga and Yamuna mark the south-eastern and north-western 
174 boundaries of the valley, respectively. Doon valley is a fragile, tectonically active

175 landscape with a climate ranging from sub-tropical to temperate type. Ecologically, the

176 valley forms a landscape-level ecotone between the hot tropical plains and the temperate

177 Himalayan mountain ecosystems. Traditionally, the farming practice consists of multiple

178 crops in different seasons of cultivation viz. Kharif, Jayad and Rabi. The major groups of

179 crops grown consist of cereals (wheat, paddy, maize, and millets), oilseeds (mustard,

180 sesame, and linseed), vegetables (potato, tomato, brinjal, radish, cabbage, okra, pea,

181 onion, capsicum, French bean, ginger, garlic) and cash crops (sugarcane)[70]. The valley

182 is famous for its variety of rice called Dehradun Basmati [71] and fruit orchards of litchi

183 [72]. Other fruit orchards commonly cultured in the valley are pear, mango, guava, peach

184 and Indian gooseberry. Numerous local citrus varieties and vegetables are grown

185 seasonally in the valley for household consumption [70]. Based on the increasing

186 demands and economic benefits, crops such as wheat and sugarcane are taking over the

187 diverse cropping system in the Himalayas [73]. One can find many monocultures and

188 polycultures in the valley based on the type and scale of farming.

Fig 1. Sampling locations for bee species in Doon valley, India.

Fig 2. Land use and land cover map of Doon valley, India.

192 Table 1. Land use and Land cover (LULC) statistics of Doon Valley (in sq. km) in

1932015 (Source: Mishra et al., 2015).

\begin{tabular}{|l|l|l|}
\hline LULC Class & Area in \% & Area in sq. km \\
\hline Urban & 39.25 & 1205.37 \\
\hline Water & 1.69 & 52.01 \\
\hline Vegetation & 8.90 & 273.34 \\
\hline
\end{tabular}




\begin{tabular}{|l|l|l|}
\hline Agriculture & 33.12 & 1016.98 \\
\hline Barren Land & 17.04 & 523.29 \\
\hline
\end{tabular}

195

\section{Study Design}

Since we wanted to compare the bee diversity in natural and agriculture areas, we sampled majorly different types of the habitats mentioned above in Doon valley. The stratified random sampling design was followed in the two habitats (natural- 13500 sq. $\mathrm{m}$ and agriculture- 7000 sq. m) across the study site. The minimum radial distance of $1 \mathrm{~km}$ was maintained between sites within a particular stratum. Sites were chosen such that a $50 \mathrm{~m}$ buffer was left from the edge of the strata. Among the natural habitats, we sampled sal Shorea robusta forests, riverine patches and small patches of diverse vegetation (teak Techtona grandis, pine Pinus roxburghii, bamboo Bambusa sp. and derelict tea Camellia sinensis plantations). Polycultures and monocultures consisting of food crops and fruit orchards were sampled among the agricultural habitats. We laid 27 sampling plots in the natural habitat and 14 plots in the agriculture. The plots were belt transects of $100 \mathrm{~m} \times 5 \mathrm{~m}$ with five subsampling plots of $5 \mathrm{~m} \times 5 \mathrm{~m}$ dimension. The study site consisted of 203 subsampling plots in the natural (Sal- 45, riverine- 60 and miscellaneous-30) and agricultural (polyculture- 33, monoculture- 35) habitats. The sampling was carried out in the peak flowering periods. Three replicates were repeated from February to May in 2012, January to May 2013 and 2014.

Bee Sampling and Identification- Bees were sampled using active and passive methods on each transect. The active methods included visual observations using a transect walk and net sweeping. Visual observations were performed with a walk along the length of the transect searching for bees up to $2 \mathrm{~m}$ on either side. Any sightings beyond this distance were ignored. It took approximately 20 minutes to complete one transect walk. Three 

pantraps to collect bees that are attracted to flower colours [74-77]. A set of three colours of plastic pantraps were used: yellow, blue and white [39]. Initially, the pantraps were left for 24 hrs. However, this duration yielded a low number to no bees. Thus, we left these pantraps for 48 hours and collected them on the third day. In total, 1827 pantrap sampling sessions were run (203 traps of three colours with three replicates) throughout the study period across the valley. Bees collected using all the different methods was appropriately curated. Specimens were stored either as a dried specimen and spread in insect boxes or as wet specimen in $70 \%$ ethanol vials till further identification. A standard identification key by Michener [4] was referred, to identify bees into families and further. We sorted the specimen into morphospecies as recognizable taxonomic units (RTU) for further data analysis [78-80].

\section{Data Analysis}

Active sampling resulted in 2799 (Sweep Net=34, Observation=2765) bee records compared to passive $(n=432)$ methods. We pooled the data obtained from both active and passive sampling to assess the species diversity of bees across different families. We calculated the bee species richness for all the habitats using non-parametric estimators

237 (Colwell and Coddington 1994). We computed the Bray-Curtis dissimilarity index to examine whether bee species composition in the two primary habitats varied in Doon valley using Analysis of Similarity (ANOSIM) [81,82]. A non-metric multidimensional scaling (NMDS) ordination was performed on the rank orders of dissimilarity values obtained from the ANOSIM. We encountered honey bees frequently $(n=2468)$ compared 
to non-Apis bees $(\mathrm{n}=331)$ in active sampling, suggesting an observation bias towards the

243 former. Hence, we used only pantrap records of bees for the ANOSIM. We performed a

244 multinomial species classification based on species habitat preferences to test the

245 association of bee compositions with natural and agricultural habitats [83]. The data for

246 all the agricultural sampling plots at varying distances from natural habitats was compiled

247 to explore whether natural habitats act as a refuge for bee communities of the

248 agroecosystems. We classified the distance of sampling plot in agriculture from the

249 nearest natural habitats into seven classes. Each distance class was $100 \mathrm{~m}$ wide beginning 250 at zero to $700 \mathrm{~m}$. Individual Shannon diversity indices $\left(\mathrm{H}^{\prime}\right)$ were computed for each of the

251 eight distance classes. We used regression analysis on the Shannon diversity for each

252 distance class to investigate if nearness to natural habitat affects the diversity of bee

253 assemblages in agroecosystems.

254 We wanted to test whether polycultures behave similarly to natural habitats compared to 255 monocultures. For this we measured the Shannon-Weiner diversity of bees across 78 256 subsampling plots from monoculture and polyculture farms near $(<100 \mathrm{~m})$ and far from 257 forests or wilderness $(>100 \mathrm{~m})$ viz. 20 monocultures near to the forest, 20 monocultures 258 far from the forest, 18 polycultures close to forest and 20 polycultures far from forest. We 259 compared the farm Shanon-Weiner diversity values with that of the different forests 260 combined.

261 The analyses were carried out in the program $\mathrm{R}$ version 3.3.1 using package "vegan"[84,85]. 
bioRxiv preprint doi: https://doi.org/10.1101/804856; this version posted October 14,2019 . The copyright holder for this preprint (which was not certified by peer review) is the author/funder, who has granted bioRxiv a license to display the preprint in perpetuity. It is made available under aCC-BY 4.0 International license.

267 five families and 17 genera (Table 2). There were thirty-nine non-Apis and

268 four Apis (Apis indica, A. florea, A. mellifera and A. dorsata) bee species.

\section{Table 2. List of bees from Doon Valley}

\begin{tabular}{|c|c|c|c|c|}
\hline No. & Family & Bee Species & $\begin{array}{l}\text { Agriculture } \\
\text { habitat }\end{array}$ & $\begin{array}{l}\text { Natural } \\
\text { habitat }\end{array}$ \\
\hline 1 & Andrenidae & Andrena Euandrena sp. 3 & + & + \\
\hline 2 & Andrenidae & Andrena Euandrena sp. 4 & + & + \\
\hline 3 & Andrenidae & Andrena flavipes & + & + \\
\hline 4 & Andrenidae & Andrena sp. 2 & + & + \\
\hline 5 & Andrenidae & Andrena sp. 3 & + & - \\
\hline 6 & Andrenidae & Andrena Zonandrena sp. 1 & + & + \\
\hline 7 & Andrenidae & Andrena sp. 4 & + & + \\
\hline 8 & Andrenidae & Andrena sp. 1 & + & + \\
\hline 9 & Apidae & Amegilla zonata & - & + \\
\hline 10 & Apidae & Anthophora sp. 2 & - & + \\
\hline 11 & Apidae & Anthophora sp. 1 & - & + \\
\hline 12 & Apidae & Apid sp. 1 & - & + \\
\hline 13 & Apidae & Apis dorsata & + & + \\
\hline 14 & Apidae & Apis florea & + & - \\
\hline 15 & Apidae & Apis indica & + & - \\
\hline 16 & Apidae & Apis mellifera & + & + \\
\hline 17 & Apidae & Bombus haemorrhoidalis & + & + \\
\hline 18 & Apidae & Ceratina smaragdula & + & + \\
\hline
\end{tabular}




\begin{tabular}{|c|c|c|c|c|}
\hline 19 & Apidae & Ceratina sp. 5 & - & + \\
\hline 20 & Apidae & Ceratina sp. 2 & - & + \\
\hline 21 & Apidae & Ceratina sp. 3 & + & + \\
\hline 22 & Apidae & Ceratina sp. 4 & - & + \\
\hline 23 & Apidae & Colletid sp. 1 & + & + \\
\hline 24 & Apidae & Tetragonula sp. 2 & + & + \\
\hline 25 & Apidae & Tetragonula sp. 1 & - & + \\
\hline 26 & Apidae & Xylocopa astuens & + & + \\
\hline 27 & Apidae & Xylocopa sp. 1 & + & + \\
\hline 28 & Halitidae & Halictid sp. 4 & - & + \\
\hline 29 & Halitidae & Halictid sp. 1 & + & + \\
\hline 30 & Halitidae & Halictus sp. 2 & + & + \\
\hline 31 & Halitidae & Halictus sp. 3 & + & + \\
\hline 32 & Halitidae & Lasioglossum sp. 2 & + & + \\
\hline 33 & Halitidae & Lasioglossum sp. 1 & - & + \\
\hline 34 & Halitidae & Nomia interstitialis & + & + \\
\hline 35 & Halitidae & Nomia sp. 1 & + & + \\
\hline 36 & Halitidae & Nomia wetwoodi & + & - \\
\hline 37 & Halitidae & Patellapis sp. 1 & - & + \\
\hline 38 & Halitidae & Sphecodes sp. 1 & + & + \\
\hline 39 & Megachilidae & Megachile lanata & - & + \\
\hline 40 & Megachilidae & Megachile sp. 1 & - & + \\
\hline 41 & Megachilidae & Megachile sp. 9 & - & + \\
\hline 42 & Megachilidae & Megchile sp. 8 & - & + \\
\hline
\end{tabular}




\begin{tabular}{|l|l|l|l|l|}
\hline 43 & Megachilidae & Osmia adae & + & + \\
\hline
\end{tabular}

272 than between habitats $(\mathrm{R}$ statistic $=0.20, \mathrm{p}=0.004)$ (Table 3). Bee composition in agroecosystems slightly overlapped with the different natural habitats. We pooled the data

274 for the different natural habitats and overlaid it on that of agroecosystems. We found that

275 arable lands shared the majority of the species with the different natural habitats in the

276 Doon valley (Fig 3).

Fig 3. Species composition of bees in different habitats in Doon valley constructed using Nonmetric Multidimensional Scaling. Overlay of bee communities between agroecosystems (green polygon) and different types of forest habitats (blue, orange, \& red). Forest habitats pooled together (black polygon).

Table 3. Comparison of bee community similarity between forest (Riverine Forest-

\begin{tabular}{|l|l|l|l|}
\hline $\boldsymbol{R F}$ & 0.33 & 0.09 & 0.23 \\
\hline $\mathbf{0 . 0 0 6}$ & $\boldsymbol{S F}$ & 0.22 & -0.01 \\
\hline 0.07 & $\mathbf{0 . 0 0 7}$ & AGR & 0.01 \\
\hline $\mathbf{0 . 0 5}$ & 0.46 & 0.409 & MIS \\
\hline
\end{tabular}



generalists and found in both the habitats. During sampling three bee species (6.98\%) viz., Dwarf bee (Apis florea), Asiatic honey bee (Apis indica), and Andrena sp. three were detected only in the agricultural habitats. It is interesting to note that these species were observed inhabiting edges and interiors of the forests in the vicinity of the the habitats for foraging and nesting and may be subjective to availability of different resources year-round.

Fig 4. Species classification into specialists (agricultural and forest habitats) and

forests ( $\mathrm{H}^{\prime}$ for $<200 \mathrm{~m}=1.60$ ) compared to those further away ( $\mathrm{H}^{\prime}$ for $>600 \mathrm{~m}=0.56$ )

$(\mathrm{R} 2=0.782, \mathrm{SE}=0.148, \mathrm{p}$ value $=0.004)($ Fig 5 $)$

Fig 5. Influence of natural habitat on bee community richness in agroecosystems (linear regression model; $\mathrm{R} 2=0.782, \mathrm{SE}=0.148, \mathrm{P}=0.004$ ).

Our results demonstrate that forests harboured the highest number of bees $(n=21)$, followed by polycultures near forests or wilderness $(n=19)$ and monoculture near the forest $(n=15)$, polyculture away from the forest $(n=13)$ and monocultures away from the forests $(n=9)$. The Shannon-Weiner diversity of forests was 2.37 , monocultures near forests were 2.13 , polycultures near forest was 2.15 , monocultures away from forest were 1.55 and polycultures away from the forest was 2.08. The bee community diversity between monocultures and polycultures close to the forests were similar than those farther 
Table 4. Shannon-Weiner diversity of bee communities in forests, monocultures and polycultures across Doon Valley, India.

\begin{tabular}{|l|l|l|}
\hline Habitat & Shannon-Weiner diversity & Species Richness \\
\hline Monoculture away from forest & 1.55 & 9 \\
\hline Monoculture near forest & 2.13 & 15 \\
\hline Polyculture away from forest & 2.08 & 13 \\
\hline Polyculture near forest & 2.15 & 19 \\
\hline Forests & 2.37 & 21 \\
\hline
\end{tabular}

\section{Discussions}

Continual land use changes to meet the needs of a growing human population are predicted to be the primary drivers of species decline [24], including essential pollinators such as bees [21]. The status of the vast majority of non-Apis bees remains uncertain 319 owing to inadequate exploration. Honey bees, on the contrary, form only a small portion 320 and yet have gained more considerable attention and became exhaustively studied. We 321 attempt to bridge this gap and investigate the role of changing land use in shaping the 322 non-Apis bee communities in a fragile river valley landscape at the foothills of the 323 Himalaya. Ours is the first study on bees of this region and may be used as baseline 324 evidence to compare future patterns in their communities locally. We found that Doon 325 valley harbours $6.3 \%$ of the 678 bee species recorded from the Indian sub-continent [86]. 
Our investigation pointed out that a majority of these species consist of the less explored non-Apis bees (90.7\%). Various bee researchers have demonstrated that honey bees (genera Apis) are a tiny fraction of the vast majority of bees described from the world over $[4,87]$. It is not surprising that the Doon valley demonstrates a similar pattern of the bee biodiversity. Many $(n=30)$ bees recorded in the present study $(n=43)$ are segregated into morphospecies and are yet to be identified up to species level. Using specific taxonomic keys for bees may increase the total number of species in India.

We found that bee composition within habitats demonstrated more significant similarity than between habitats in Doon valley. Interestingly, the bee composition of the agroecosystems was a subset of the natural habitats. Bees require a diverse habitat with resources for breeding, nesting, and foraging to complete their life cycles. All the resources required may be unavailable within the habitats that bees occupy. For example, some bees depend on particular plant pollen for proteins that may be highly nutritious for reproduction [88]. However, flowers with such protein-rich pollen may not bloom year 340 around always, which makes them move from one habitat patch to another.

341 Agroecosystems are abundant sources of mass flowering and may serve as a food support system for bees at a particular time of the year. Thus, numerous bees utilize both natural

343 and human-managed ecosystems such as cropland to suffice their nutritional, sheltering 344 and their reproduction requirements $[22,41,43,44,88]$. We sampled the bees in the peak 345 flowering period in Doon valley. During this is the period many farms in the valley have 346 abundant vegetables, fruits and oilseed plants in the various stages of flowering. Although 347 most bees nested in different natural habitats, agroecosystems may act as rich foraging 348 grounds for some species during the spring in the valley. Thus, the bee composition of 349 agroecosystems overlapped partially with that of the natural habitats in the valley. 
Our study highlighted that more than half of the bees in the valley were rare. Patterns of

351 the rarity of bees through a large number of singletons reported may arise because of

352 under-sampling, an unrecognized universal trait of a rarity in communities or existence of

353 transient species that thrive well in other regions [89]. Williams et al. [89] tried to

354 understand the change in bee communities across the globe. They highlighted that the

355 native bee community are highly diverse and rich in rare species at local scales (due to a

356 large number of singletons at such scales). Several other researchers reported this pattern

357 in various studies across regions [90-94]. We sampled the valley in peak flowering

358 season, which may answer a part of the question of a rarity in species due to under-

359 sampling during other seasons. Considering that Doon Valley is a transition between two

360 different ecosystems, the other two possibilities of a large number of a rarity in

361 communities based on a universal pattern and transient species cannot be ruled out.

362 Over one-fourth of the bees, we recorded from the valley preferred natural habitats of the

363 forests. Few generalist species were found in both the habitats. Interestingly, 3 of the bee

364 species viz. Dwarf bee (Apis florea), Asiatic honey bee (Apis indica), and Andrena sp. 3)

365 were classified to prefer agroecosystems. Apis florea prefers bushy shrubs with strong

366 twigs to make their nests. Thus, they are highly sensitive to incidences, such as fires.

367 Forest fires are frequent in the valley from mid to end of the spring. Activities such as

368 leftover cigarette buds discarded by humans venturing into the forests for extracting

369 fodder and firewood usually trigger forest fires. They are intensified further by the dry

370 season. Hence, farm boundaries and hedgerows form favourable spaces for the dwarf bees

371 to build their nests beside the availability of abundant food in the spring. The Asiatic

372 honey bees are generalist feeders and feed in large numbers in farmlands with abundant

373 flowering crops. One can observe these bees foraging in large numbers on mustard and

374 other flowering crops in Doon valley in the spring. During different seasons these bees 
are seen foraging on a diversity of wild and cultivated plants. They reside in parallel combs similar to their close cousins, the Apis mellifera in hollows of trees, rocks or undisturbed enclosed spaces in case of urban areas. Finding $A$. indica hives in farmlands are rare unless there are intact patches of large trees with hollows or rocky patches. Forests are suitable and typical habitats to find these bees. Andrena bees nest on welldrained, steep open banks [95]. Field boundaries that are used to segregate different crops in Doon valley provide such habitats in abundance. Morandin et al. [40] reported similar observations in their study where untilled field margins adjoining roads provided suitable habitats for Andrena bees to nest. Hence, these three species should be treated as facultative rather than specialists as they utilize resources from both the forests and the agroecosystems.

Agroecosystems at increasing distances from the natural habitats demonstrated lower bee diversity in our study. Numerous studies in the past reported similar findings. Pollinators depend on natural and semi-natural habitats adjacent to agroecosystems for supplemental food resources and shelter [6,96-98]. Wild bees in forests demonstrate limited foraging ranges. The valuable services of these bees influence agroecosystems in the vicinity of forests [7]. Maintaining natural habitats within or surrounding the agroecosystems crucial for wild bee pollination services [99].

Our results illustrate that monocultures close to forest ecosystems show diverse bee communities than those farther away. Surprisingly, the bee richness in polycultures away from the forests was similar to monocultures in close vicinity of the forests. Our results demonstrate that polycultures behave similar to natural habitat in conserving bees. The outcomes of our study indicate that polyculture farms had rich bee species compared to monoculture. Earlier studies (Potts et al. 2003) showed that bee communities are positively linked to floral diversities and prefer polyculture over monoculture [100]. The 
traditional Himalayan agriculture consists of diverse crops [101]. Polyculture systems that we sampled consisted of different crops in combinations of 2 to 4 species and wildflowers on the bunds to segregate them, which may have supported a rich composition of bees. On the contrary, our study recorded fewer bee species in monocultures of wheat (Triticum spp.) and mustard (Brassica juncea (L.) Czern). Wheat is wind-pollinated and does not provide biotic pollinating agents with rewards such as nectar and pollen. In monoculture, we found most bee species on mustard or on wild invasive plants such as Lantana camara and Ageratum conyzoides that grew on the boundaries of the farms. Polycultures have a greater diversity of native plants than monocultures which influences the bee biodiversity in agroecosystems [102]. Our findings demonstrate that forests are reservoirs of diverse bee communities in adjoining patches of agroecosystems. The present analysis supports the fact that polycultures act as reservoirs of habitat to bees compared to monocultures in close vicinity to natural habitats.

\section{Conclusions}

Our investigation on bees in Doon valley, a landscape with gradual changing LULC at the foot of the Himalaya, is the first one to document the bees (Apis and nonApis) in the forest and agricultural habitats of the region. Our findings demonstrate that the Doon valley landscape and its natural habitats are a refuge to a diverse community of rare and specialist bees. Agroecosystems shared a lot more species in common with each of the natural habitats. Forests and wilderness are essential habitats to support diverse bee communities in and around the agroecosystems. Furthermore, polycultures support higher bee diversities over monoculture practices. Wilderness along field boundaries such as hedges stands as connectivity between different habitats. Monoculture expansions have 
427 production.

443 simultaneously. An assessment on similar lines is needed to understand bee diversity 444 occupying natural and arable habitats in the tropical and sub-tropical regions of the world.

445 Besides, it is crucial to understand what percentage of these bees support crop production

diminished these vital corridors [38,103,104], affecting the survival of pollinators [45]. Our study implies the importance of multi-crop farming and preserving as many natural habitats as possible to attract native bees and benefit both cultivated and wild plant The global tree cover shows an increase of 7\% (2.24 million sq. km) from 1982 to 2016 (Song et al. 2018), differing from a previous assessment claiming loss of forest (FAO 2015). India was ranked first in short vegetation gain (270,000 sq. km), most of which can be attributed to the agricultural intensification under the green revolution [105]. Extension of land under intensive agrarian practices is a prime cause of deforestation and loss of wilderness habitats. Wilderness play buffers to biodiversity that have lost intact natural habitats. Loss of wilderness causes the extinction of several terrestrial species across the global biogeographic realms, including the Indomalayan region [106]. Loss of wilderness habitats comprising of essential resources can drive local pollinators depending on them to extinction. Our investigation highlights that natural habitats are integral to bee diversity. In the milieu of honey bee decline worldwide Polycultures give some hope to non-Apis bee diversity in a Himalayan valley landscape. Thus, there is a ray of hope to "land sharing and sparing" as Baurdon and Giller to feed a growing population [107]. Using ecologically friendly farming such as polycultures nutritious biodiverse food for a growing population can be produced while conserving wild pollinators 


\section{Acknowledgements}

We are grateful to the Director, Wildlife Institute of India, Director and Staff of

450 Dehradun Forest Division, Uttarakhand. We thank the Department of Entomology, Indian

451 Agricultural Research Institute, New Delhi for the guidance and identification of the

452

453 specimen. We would like to extend our gratitude to Research Foundation for Science, Technology and Ecology, Navdanya Trust, New Delhi for their support to work with farmers. We are grateful to the State Biotechnology Department, Government of Uttarakhand, India. (SBD/R\&D/01/11/02-87) for funding the study. We are indebted to the farmers in Doon valley for their cooperation in letting us conduct uninterrupted field work for the study.

\section{References}

1. Aguilar R, Ashworth L, Galetto L, Aizen MA. Plant reproductive susceptibility to habitat fragmentation: Review and synthesis through a meta-analysis. Ecol Lett. 2006;9: 968-980. doi:10.1111/j.1461-0248.2006.00927.x

2. Ashman T-L, Knight TM, Steets JA, Amarasekare P, Burd M, Campbell DR, et al. Pollen Limitation of Plant Reproduction: Ecological and Evolutionary Causes and Consequences. Ecology. 2004;85: 2408-2421. doi:10.1890/03-8024

3. Michener CD. Biogeography of the Bees. Ann Missouri Bot Gard. 1979;66: 277347.

4. Michener CD. The Bees of the World. Baltimore, Maryland: The John Hopkins University Press; 2007. 
5. Klein A-MM, Vaissière BE, Cane JH, Steffan-Dewenter I, Cunningham SA, Kremen C, et al. Importance of pollinators in changing landscapes for world crops. Proc R Soc B Biol Sci. 2007;274: 303-313. doi:10.1098/rspb.2006.3721

6. Kremen C, Williams NM, Thorp RW. Crop pollination from native bees at risk from agricultural intensification. Proc Natl Acad Sci. 2002;99: 16812-16816. doi:10.1073/pnas.262413599

7. Ricketts TH. Tropical Forest Fragments Enhance Pollinator Activity in Nearby Coffee Crops. Conserv Biol. 2004;18: 1262-1271. doi:10.1111/j.15231739.2004.00227.x

8. National Research Council. Status of Pollinators in North America. Naitonal Acad Press. Naitonal Academies Press; 2006.

9. vanEngelsdorp D, Meixner MD. A historical review of managed honey bee populations in Europe and the United States and the factors that may affect them. $\mathrm{J}$ Invertebr Pathol. 2010;103: S80-S95. doi:10.1016/j.jip.2009.06.011

10. Potts SG, Roberts SPM, Dean R, Marris G, Brown MA, Jones R, et al. Declines of managed honey bees and beekeepers in Europe. J Apic Res. 2010;49: 15-22. doi:10.3896/IBRA.1.49.1.02

11. Potts SG, Biesmeijer JC, Kremen C, Neumann P, Schweiger O, Kunin WE. Global pollinator declines: trends, impacts and drivers. Trends Ecol Evol. 2010;25: 345353. doi:10.1016/j.tree.2010.01.007

12. Buchmann SL, Nabhan GP. Forgotten Pollinators. Washington D.C.: Island Press; 1996.

13. Memmott J, Craze PG, Waser NM, Price M V. Global warming and the disruption 
493

494

of plant?pollinator interactions. Ecol Lett. 2007;10: 710-717. doi:10.1111/j.14610248.2007.01061.x

14. Burkle LA, Marlin JC, Knight TM. Plant-Pollinator Interactions over 120 Years: Loss of Species, Co-Occurrence, and Function. Science (80- ). 2013;339: 16111615. doi:10.1126/science. 1232728

15. Alston DG, Tepedino VJ, Bradley B a, Toler TR, Griswold TL, Messinger SM. Effects of the Insecticide Phosmet on Solitary Bee Foraging and Nesting in Orchards of Capitol Reef National Park, Utah. COMMUNITY Ecosyst Ecol Environ Entomol. 2007;36: 811-816. doi:10.1603/0046225X(2007)36[811:EOTIPO]2.0.CO;2

16. Gilburn AS, Bunnefeld N, Wilson JM, Botham MS, Brereton TM, Fox R, et al. Are neonicotinoid insecticides driving declines of widespread butterflies? PeerJ. 2015;3: e1402. doi:10.7717/peerj.1402

17. Traveset A, Richardson DM. Biological invasions as disruptors of plant reproductive mutualisms. Trends Ecol Evol. 2006;21: 208-216. doi:10.1016/j.tree.2006.01.006

18. Thomson DM. Detecting the Effects of Introduced Species : A Case Study of Competition between Apis and the effects of introduced of species : a case study Detecting between Apis and Bombus competition. Oikos. 2006;114: 407-418. doi:10.1111/j.2006.0030-1299.14604.x

19. Favre D. Mobile phone-induced honeybee worker piping. Apidologie. 2011;42: 270-279. doi:10.1007/s13592-011-0016-x

20. Cox-Foster DL, Conlan S, Holmes EC, Palacios G, Evans JD, Moran NA, et al. A 
Metagenomic Survey of Microbes in Honey Bee Colony Collapse Disorder. Science (80- ). 2007;318: 283-287. doi:10.1126/science.1146498

21. Bommarco R, Kleijn D, Potts SG. Ecological intensification: harnessing ecosystem services for food security. Trends Ecol Evol. 2013;28: 230-238. doi:10.1016/j.tree.2012.10.012

22. Kremen C, Williams NM, Aizen MA, Gemmill-Herren B, LeBuhn G, Minckley R, et al. Pollination and other ecosystem services produced by mobile organisms: a conceptual framework for the effects of land-use change. Ecol Lett. 2007;10: 299314. doi:10.1111/j.1461-0248.2007.01018.x

23. Tylianakis JM, Tscharntke T, Lewis OT. Habitat modification alters the structure of tropical host-parasitoid food webs. Nature. 2007;445: 202-205. doi:10.1038/nature05429

24. Sala OE. Global Biodiversity Scenarios for the Year 2100\&amp;nbsp; Science (80). 2000;287: 1770-1774. doi:10.1126/science.287.5459.1770

25. Larigauderie A, Prieur-Richard A-H, Mace GM, Lonsdale M, Mooney HA, Brussaard L, et al. Biodiversity and ecosystem services science for a sustainable planet: the DIVERSITAS vision for 2012-20. Curr Opin Environ Sustain. 2012;4: 101-105. doi:10.1016/j.cosust.2012.01.007

26. Pereira HM, Navarro LM, Martins IS. Global Biodiversity Change: The Bad, the Good, and the Unknown. Annu Rev Environ Resour. 2012;37: 25-50. doi:10.1146/annurev-environ-042911-093511

27. Ghazoul J. Buzziness as usual? Questioning the global pollination crisis. Trends Ecol Evol. 2005;20: 367-373. doi:10.1016/j.tree.2005.04.026 
28. United Nations. World Urbanization Prospects The 2007 Revision. Prospects. 2008; 1-22. doi:10.2307/2808041

29. United Nations, UNDESA. World Urbanization Prospects The 2007 Revision Highlights. New York. 2007;ESA/P/WP/2: 883. doi:10.2307/2808041

30. Tilman D, Fargione J, Wolff B, D’Antonio C, Dobson A, Howarth R, et al. Forecasting Agriculturally Driven Global Environmental Change. Science (80- ). 2001;292: 281-284. doi:10.1126/science.1057544

31. Food and Agriculture Organization. Global Forest Resources Assessment 2015: How are the world's forests changing? Food Agric Organ United Nations. Rome; 2015 Jun. Available: http:/www.fao.org/forestry/fra2005/en/

32. Tian H, Banger K, Bo T, Dadhwal VK. History of land use in India during 18802010: Large-scale land transformations reconstructed from satellite data and historical archives. Glob Planet Change. 2014;121: 78-88. doi:10.1016/j.gloplacha.2014.07.005

33. Bailey S, Requier F, Nusillard B, Roberts SPM, Potts SG, Bouget C. Distance from forest edge affects bee pollinators in oilseed rape fields. Ecol Evol. 2014;4: 370380. doi:10.1002/ece3.924

34. Brosi BJ, Daily GC, Shih TM, Oviedo F, Durán G. The effects of forest fragmentation on bee communities in tropical countryside. J Appl Ecol. 2007;45: 773-783. doi:10.1111/j.1365-2664.2007.01412.x

35. Gemmill-Herren B, Ochieng' AO. Role of native bees and natural habitats in eggplant (Solanum melongena) pollination in Kenya. Agric Ecosyst Environ. 2008;127: 31-36. doi:10.1016/j.agee.2008.02.002 
36. Roulston TH, Goodell K. The Role of Resources and Risks in Regulating Wild Bee Populations. Annu Rev Entomol. 2011;56: 293-312. doi:10.1146/annurev-ento$120709-144802$

37. Biesmeijer JC, Roberts SPM, Reemer M, Ohlemüller R, Edwards M, Peeters T, et al. Parallel Declines in Pollinators and Insect-Pollinated Plants in Britain and the Netherlands. Science (80- ). 2006;313: 351-354. doi:10.1126/science.1127863

38. Robinson RA, Sutherland WJ. Post-war changes in arable farming and biodiversity in Great Britain. J Appl Ecol. 2002;39: 157-176. doi:10.1046/j.13652664.2002.00695.x

39. Westphal C, Bommarco R, Carré G, Lamborn E, Morison N, Petanidou T, et al. MEASURING BEE DIVERSITY IN DIFFERENT EUROPEAN HABITATS AND BIOGEOGRAPHICAL REGIONS. Ecol Monogr. 2008;78: 653-671. doi:10.1890/07-1292.1

40. Morandin LA, Winston ML, Abbott VA, Franklin MT. Can pastureland increase wild bee abundance in agriculturally intense areas? Basic Appl Ecol. 2007;8: 117124. doi:10.1016/j.baae.2006.06.003

41. Coll M. Conservation biological control and the management of biological control services: are they the same? Phytoparasitica. 2009;37: 205-208. doi:10.1007/s12600-009-0028-5

42. Goulson D, Darvill B. Niche overlap and diet breadth in bumblebees; are rare species more specialized in their choice of flowers? Apidologie. 2004;35: 55-63. doi:10.1051/apido:2003062

43. Minckley RL, Roulston TH, Williams NM. Resource assurance predicts specialist 

and generalist bee activity in drought. Proc R Soc B Biol Sci. 2013;280: 20122703. doi:10.1098/rspb.2012.2703

44. Tscharntke T, Klein AM, Kruess A, Steffan-Dewenter I, Thies C. Landscape perspectives on agricultural intensification and biodiversity - ecosystem service management. Ecol Lett. 2005;8: 857-874. doi:10.1111/j.1461-0248.2005.00782.x

45. Vanbergen AJ, Initiative the IP. Threats to an ecosystem service: pressures on pollinators. Front Ecol Environ. 2013;11: 251-259. doi:10.1890/120126

46. Ginsberg HS. Foraging Movements of Halictus ligatus (Hymenoptera: Halictidae) and Ceratina calcarata (Hymenoptera: Anthophoridae) on Chrysanthemum leucanthemum and Erigeron annuus. J Kansas Entomol Soc. 1985;58: 19-26.

47. Ginsberg HS. Foraging Ecology of Bees in an Old Field. Ecology. 1983;64: 165175. doi: $10.2307 / 1937338$

48. Goulson D, Lye GC, Darvill B. Decline and Conservation of Bumble Bees. Annu Rev Entomol. 2008;53: 191-208. doi:10.1146/annurev.ento.53.103106.093454

49. Goulson D, Lepais O, O’Connor S, Osborne JL, Sanderson RA, Cussans J, et al. Effects of land use at a landscape scale on bumblebee nest density and survival. J Appl Ecol. 2010;47: 1207-1215. doi:10.1111/j.1365-2664.2010.01872.x

50. Power AG. Ecosystem services and agriculture: tradeoffs and synergies. Philos Trans R Soc B Biol Sci. 2010;365: 2959-2971. doi:10.1098/rstb.2010.0143

51. Matson PA, Parton WJ, Poser AG, M J S. Agricultural Intensification and Ecosystem Properties. Science (80- ). 1997;277: 504-509. doi:10.1126/science.277.5325.504

52. Roubik DW. Pollination of cultivated plants in the tropics. Roubik DW, editor. 
608

609

610

611

612

613

614

615

616

617

618

619

620

621

622

623

624

625

626

627

628

629

630

Agricultural Services Bulletin. 1995. Available: http://www.fao.org/3/a-v5040e.pdf

53. Xu J, Grumbine RE, Shrestha A, Eriksson M, Yang X, Wang YUN, et al. The Melting Himalayas : Cascading Effects of Climate Change on Water, Biodiversity , and Livelihoods. Conserv Biol. 2009;23: 520-530. doi:10.1111/j.15231739.2009.01237.x

54. Klein JA, Harte J, Zhao X-Q. Experimental warming causes large and rapid species loss, dampened by simulated grazing, on the Tibetan Plateau. Ecol Lett. 2004;7: 1170-1179. doi:10.1111/j.1461-0248.2004.00677.x

55. Podani J, Schmera D. On dendrogram based measures of functional diversity. Oikos. 2006;1: 179-185. doi:10.1111/j.2006.0030-1299.15048.x

56. Walker MD, Wahren CH, Hollister RD, Henry GHR, Ahlquist LE, Alatalo JM, et al. From The Cover: Plant community responses to experimental warming across the tundra biome. Proc Natl Acad Sci. 2006;103: 1342-1346. doi: $10.1073 /$ pnas.0503198103

57. Saavedra F, Inouye DW, Price M V., Harte J. Changes in flowering and abundance of Delphinium nuttallianum (Ranunculaceae) in response to a subalpine climate warming experiment. Glob Chang Biol. 2003;9: 885-894. doi:10.1046/j.13652486.2003.00635.x

58. Kudo G, Ida TY. Early onset of spring increases the phenological mismatch between plants and pollinators. Ecology. 2013;94: 2311-2320. doi:10.1890/122003.1

59. Williams JW, Jackson ST. Novel climates, no-analog communities, and ecological surprises. Front Ecol Environ. 2007;5: 475-482. doi:10.1890/070037 
60. Xu J, Badola R, Chettri N, Chaudhary RP, Zomer R, Pokhrel B, et al. Sustaining Biodiversity and Ecosystem Services in the Hindu Kush Himalaya. Springer International Publishing; 2019. doi:10.1007/978-3-319-92288-1

61. Global Pollination Project. Conservation \& Management of Pollinators for Sustainable Agriculture through an Ecosystem Approach. In: Food and Agriculture Organization of the United Nations [Internet]. 2015 p. 1. Available: https://www.thegef.org/project/conservation-management-pollinators-sustainableagriculture-through-ecosystem-approach

62. Partap U, Pratap T. Warning Signals from the Apple valleys of the Hindu KushHimalayas: Productivity Concerns and Pollination Problems. Kathmandu, Nepal; 2002.

63. Pratap U, Pratap T. Managed Crop Pollination: The Missing Dimension of Mountain Agricultural Productivity. Kathmandu, Nepal: International Centre for Integrated Mountain Development; 1997.

64. Gurung MB, Partap U, Sharma HK, Islam N, Tamag NB. Beekeeping Training for Farmers in the Himalayas - Resource Manual for Trainers. Kathmandu, Nepal: International Centre for Integrated Mountain Development, Kathmandu; 2012.

65. Ahmad F, Joshi SR, Gurung MB. The Himalayan Cliff Bee Apis laboriosa and the honey Hunters of Kaski - Indegenous Honeybees of the Himalayas (Vol 1). Kathmandu, Nepal: International Centre for Integrated Mountain Development; 2003.

66. Verma L, Partap U. The Asian hive bee, Apis cerana, as a pollinator in vegetable seed production. Kathmandu, Nepal: International Centre for Integrated Mountain Development; 1993. 
655

656

657

658

659

660

661

662

663

664

665

666

667

668

669

670

671

672

673

674

675

676

677

678

67. Pratap U. Honeybees and Ecosystem Services in the Himalayas. In: Spehn EM, Rudmann-Maurer K, Körner C, Maselli D, editors. Mountain Biodiversity and global change. Global Mountain Biodiversity Assessment (GMBA) of DIVERSITAS, Institute of Botany, University of Basel with the support of the Swiss Agency for Development and Cooperation (SDC); 2010. doi:10.1016/j.cca.2007.05.017

68. Pratap U. Innovations in revival strategies for declining pollinators with particular reference to the indigenous honey bees: experiences of ICIMOD's initiatives in the Hindu Kush-Himalayan region. In: Verma AK, Bhardwaj SP, Gupta PR, editors. Proceedings of the Naitonal Symposium "Perspectives and Challanges of Integrated Pest Managemnt for Sustainable Agriculture”, Himachal Pradesh, India, 19-21, November 2010. Indian Society of Pest Management and Economic Zoology; 2010. pp. 85-95.

69. Jiju JS, Kumar A, Uniyal VP. Preliminary Study on Diversity of Insect Pollinators in Navdanya Organic Farm, Dheradun, Uttarakhand, India. Indian For. 2017;143: $1042-1045$.

70. Agricultural Department. Agricultural Statistics Data. In: Agriculture Department Govt. Of Uttarakhand [Internet]. 2019 p. 1. Available:

http://agriculture.uk.gov.in/pages/show/221-agriculture-statistics-data

71. Bhattacharjee P, Singhal RS, Kulkarni PR. Basmati rice: a review. Int J Food Sci Technol. 2002;37: 1-12. doi:10.1046/j.1365-2621.2002.00541.x

72. Mahajan BVC, Dillon BS. Evaluation of different cultivars of litchi (Litchi chinensis) under sub-montaneous regions of Punjab. Haryana J Hortic Sci. 2000;29: 184 ref.2. 
679

680

681

682

683

684

685

686

687

688

689

690

691

692

693

694

695

696

697

698

699

700

701

73. Pande PC, Vibhuti V, Awasthi P, Bargali K, Bargali SS. Agro-Biodiversity of Kumaun Himalaya, India: A Review. Curr Agric Res J. 2016;4: 16-34. doi:10.12944/CARJ.4.1.02

74. Lebuhn G, Droege S, Connor EF, Gemmill-Herren B, Potts SG, Minckley RL, et al. Detecting insect pollinator declines on regional and global scales. Conserv Biol. 2013;27: 113-20. doi:10.1111/j.1523-1739.2012.01962.x

75. Lebuhn G, Griswold T, Minckley R, Droege S, Roulson T, Cane J, et al. A standardized method for monitoring Bee Populations - The Bee inventory (BI) Plot. 2003. p. 11. Available: http://online.sfsu.edu/beeplot/pdfs/Bee Plot 2003.pdf

76. Leong JM, Thorp RW. Colour-coded sampling: the pan trap colour preferences of oligolectic and nonoligolectic bees associated with a vernal pool plant. Ecol Entomol. 1999;24: 329-335. doi:10.1046/j.1365-2311.1999.00196.x

77. Toler TR, Evans EW, Tepedino VJ. Pan-trapping for bees (Hymenoptera : Apiformes) in Utah's West Desert: the importance of color diversity. Pan-Pac Entomol. 2005;81: 103-113.

78. Barratt BIP, Derraik JGB, Rufaut CG, Goodman AJ, Dickinson KJM. Morphospecies as a substitute for Coleoptera species identification, and the value of experience in improving accuracy. J R Soc New Zeal. 2003;33: 583-590. doi:10.1080/03014223.2003.9517746

79. Derraik JGB, Early JW, Closs GP, Dickinson KJM. Morphospecies and Taxonomic Species Comparison for Hymenoptera. J Insect Sci. 2010;10: 1-7. doi:10.1673/031.010.10801

80. Derraik JGB, Closs GP, Dickinson KJM, Sirvid P, Barratt BIP, Patrick BH. 
Arthropod Morphospecies versus Taxonomic Species: a Case Study with Araneae, Coleoptera, and Lepidoptera. Conserv Biol. 2002;16: 1015-1023. doi:10.1046/j.1523-1739.2002.00358.x

81. Clarke KR, Warwick RM. Change in marine communities: an approach to statistical analysis and interpretation. Plymouth; 2001.

82. Clarke K, Gorley R. PRIMER v5: User Manual/Tutorial. Plymouth, UK: PRIMER-E; 2001. p. 91.

83. Chazdon RL, Chao A, Colwell RK, Lin S-Y, Norden N, Letcher SG, et al. A novel statistical method for classifying habitat generalists and specialists. Ecology. 2011;92: 1332-1343. doi:10.1890/10-1345.1

84. Oksanen J. Vegan: ecological diversity. R Doc. 2016; 12. doi:10.1029/2006JF000545

85. R Core Team. R: A language and environment for statistical computing. $\mathrm{R}$ Foundation for Statistical Computing, Vienna, Austria. 2016. Available: https://www.r-project.org/

86. Ascher JS, Pickering J. Discover Life bee species guide and world checklist (Hymenoptera: Apoidea: Anthophila). In: Discover Life [Internet]. 2018. Available: http://www.discoverlife.org/mp/20q?guide=Apoidea_species

87. Garimaldi D, Engel MS. Evolution of the Insects. New York: Cambridge University Press; 2005.

88. Goulson D, Darvill B. Niche overlap and diet breadth in bumblebees; are rare species more specialized in their choice of flowers? Apidologie. 2004;35: 55-63. doi:10.1051/apido:2003062 
89. Williams NM, Minckley RL, Silveira FA. Variation in Native Bee Faunas and its Implications for Detecting Community Changes. Conserv Ecol. 2001;5: art7. doi:10.5751/ES-00259-050107

90. Sakagami SF, Fukuda H. Instructions for use Wild Bee Survey at the Campus of Hokkaido Universityl ). Zoology. 1973;19: 190-250.

91. Tepedino AVJ, Stanton NL. Nordic Society Oikos Diversity and Competition in Bee-Plant Communities on Short-Grass Prairie Published by : Wiley on behalf of Nordic Society Oikos Stable URL : http://www.jstor.org/stable/3544376

REFERENCES Linked references are available on JSTOR for. Oikos. 1981;36: $35-44$.

92. Silveira FA, Rocha LB, Cure JR, Oliveira MJ. Abelhas silvestres (Hymenoptera, Apoidea) da Zona da Mata de Minas Gerais. II. Diversidade, abundância e fontes de alimento em uma pastagem abandonada em Ponte Nova. Rev Bras Entomol. 1993;37: 595-610.

93. Carvalho AMC, Bego LR. Studies on Apoidea fauna of cerrado vegetation at the Panga Ecological Reserve, Uberlândia, MG, Brazil. Rev Bras Entomol. 1996;40: $147-156$.

94. Timberlake PH, Michener CD. The bees of the genus Proteriades. Univ Kansas Sci Bull. 1950;XXXIII: 387-430.

95. Michener CD, McGinley RJ, Danforth BN. The Bee Genera of North and Central America (Hymenoptera: Apoidea). Simthsonian Institution Press. Washington, DC.: Smithsonian Institution Press; 1994. Available: http://www.euppublishing.com/doi/abs/10.3366/anh.1995.22.1.141 
96. Mas AH, Dietsch T V. LINKING SHADE COFFEE CERTIFICATION TO BIODIVERSITY CONSERVATION: BUTTERFLIES AND BIRDS IN CHIAPAS, MEXICO. Ecol Appl. 2004;14: 642-654. doi:10.1890/02-5225

97. Ricketts TH, Regetz J, Steffan-Dewenter I, Cunningham SA, Kremen C, Bogdanski A, et al. Landscape effects on crop pollination services: Are there general patterns? Ecol Lett. 2008;11: 499-515. doi:10.1111/j.14610248.2008.01157.x

98. Banks JE, Hannon LM, Dietsch T V., Chandler M. Effects of seasonality and farm proximity to forest on Hymenoptera in Tarrazú coffee farms. Int J Biodivers Sci Ecosyst Serv Manag. 2014;10: 128-132. doi:10.1080/21513732.2014.905494

99. Klein A-MM, Steffan-Dewenter I, Tscharntke T. Fruit set of highland coffee increases with the diversity of pollinating bees. Proc Biol Sci. 2003;270: 955-61. doi:10.1098/rspb.2002.2306

100. Baños-Picón L, Torres F, Tormos J, Gayubo SF, Asís JD. Comparison of two Mediterranean crop systems: Polycrop favours trap-nesting solitary bees over monocrop. Basic Appl Ecol. 2013;14: 255-262. doi:10.1016/j.baae.2012.12.008

101. Maikhuri RK, Rao KS, Saxena KG. Traditional crop diversity for sustainable development of Central Himalayan agroecosystems. Int J Sustain Dev World Ecol. 1996;3: 8-31. doi:10.1080/13504509609469926

102. Briggs HM, Perfecto I, Brosi BJ. The Role of the Agricultural Matrix: Coffee Management and Euglossine Bee (Hymenoptera: Apidae: Euglossini) Communities in Southern Mexico. Environ Entomol. 2013;42: 1210-1217. doi:10.1603/EN13087 
771 103. Morandin LA, Kremen C. Hedgerow restoration promotes pollinator populations

772

773 and exports native bees to adjacent fields. Ecol Appl. 2013;23: 829-839.

104. Morandin LA, Kremen C. Bee Preference for Native versus Exotic Plants in Restored Agricultural Hedgerows. Restor Ecol. 2013;21: 26-32. doi:10.1111/j.1526-100X.2012.00876.X

105. Evenson RE, Golin D. Assessing the Impact of the Green Revolution, 1960 to 2000. Science (80- ). 2003;300: 758-762. doi:10.1126/science.1078710

106. Di Marco M, Ferrier S, Harwood TD, Hoskins AJ, Watson JEM. Wilderness areas halve the extinction risk of terrestrial biodiversity. Nature. 2019. doi:10.1038/s41586-019-1567-7

107. Baudron F, Giller KE. Agriculture and nature: Trouble and strife? Biol Conserv. 2014;170: 232-245. doi:10.1016/j.biocon.2013.12.009 


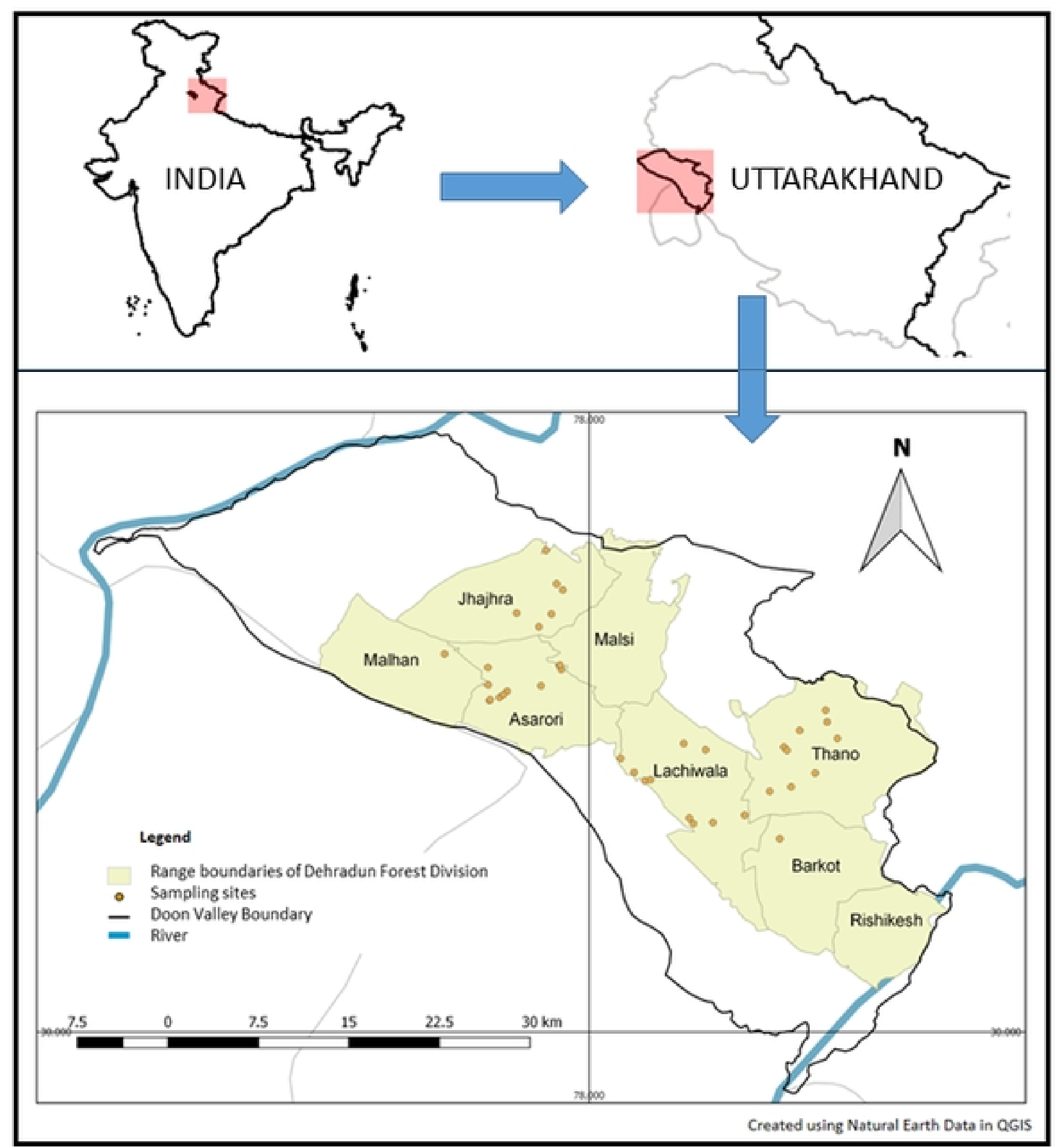

Figure 


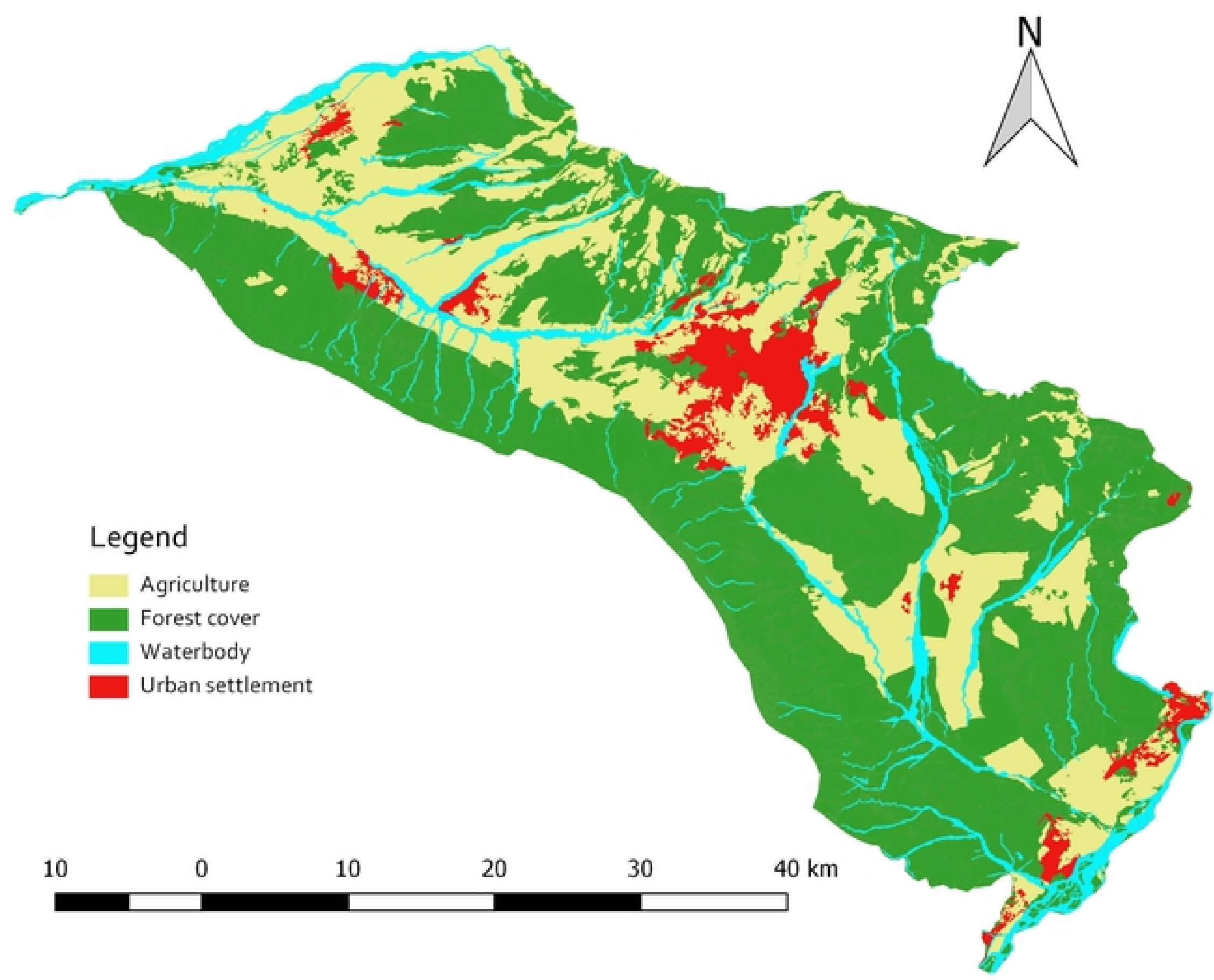

Figure 


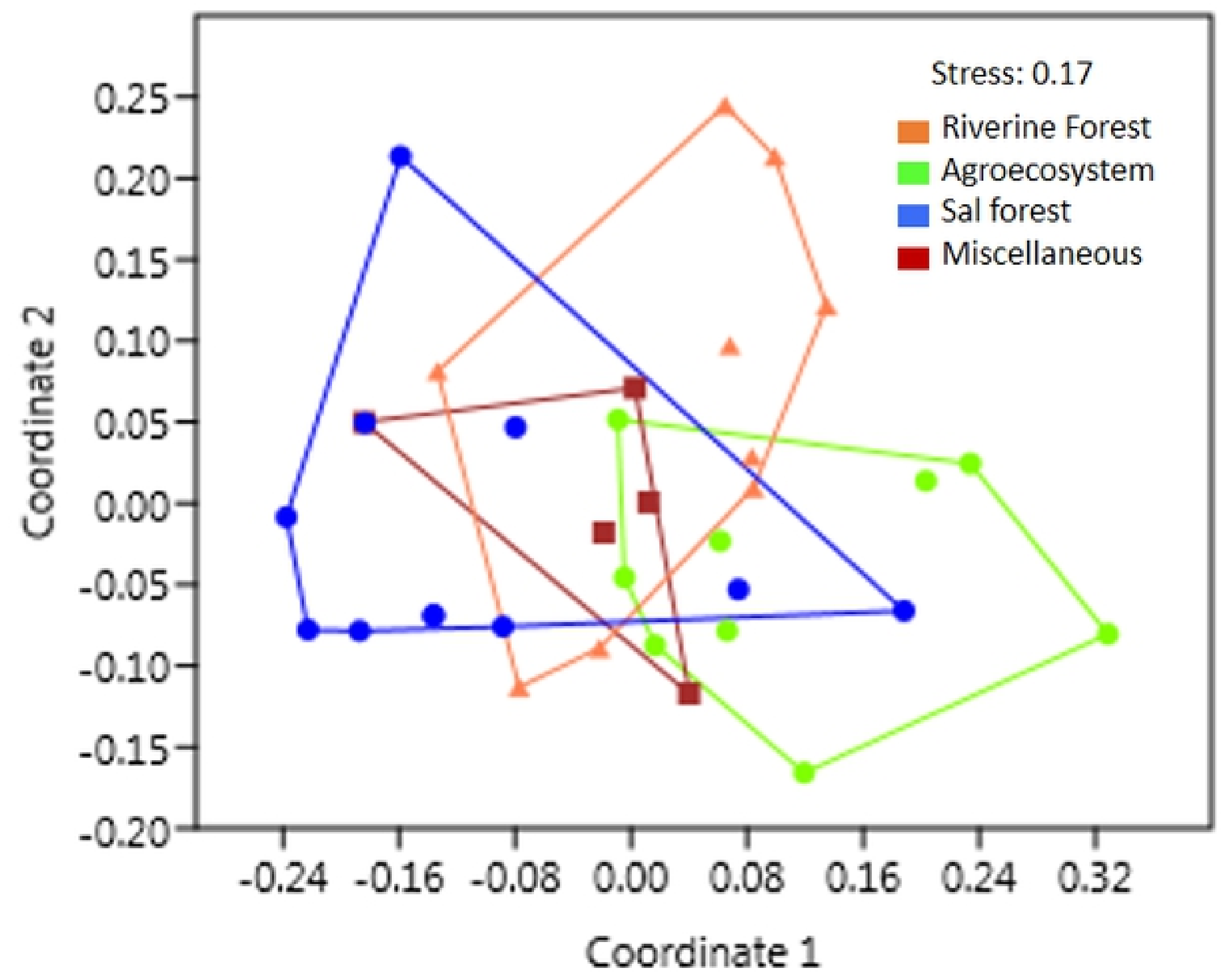

Figure 


\section{Species Classification}

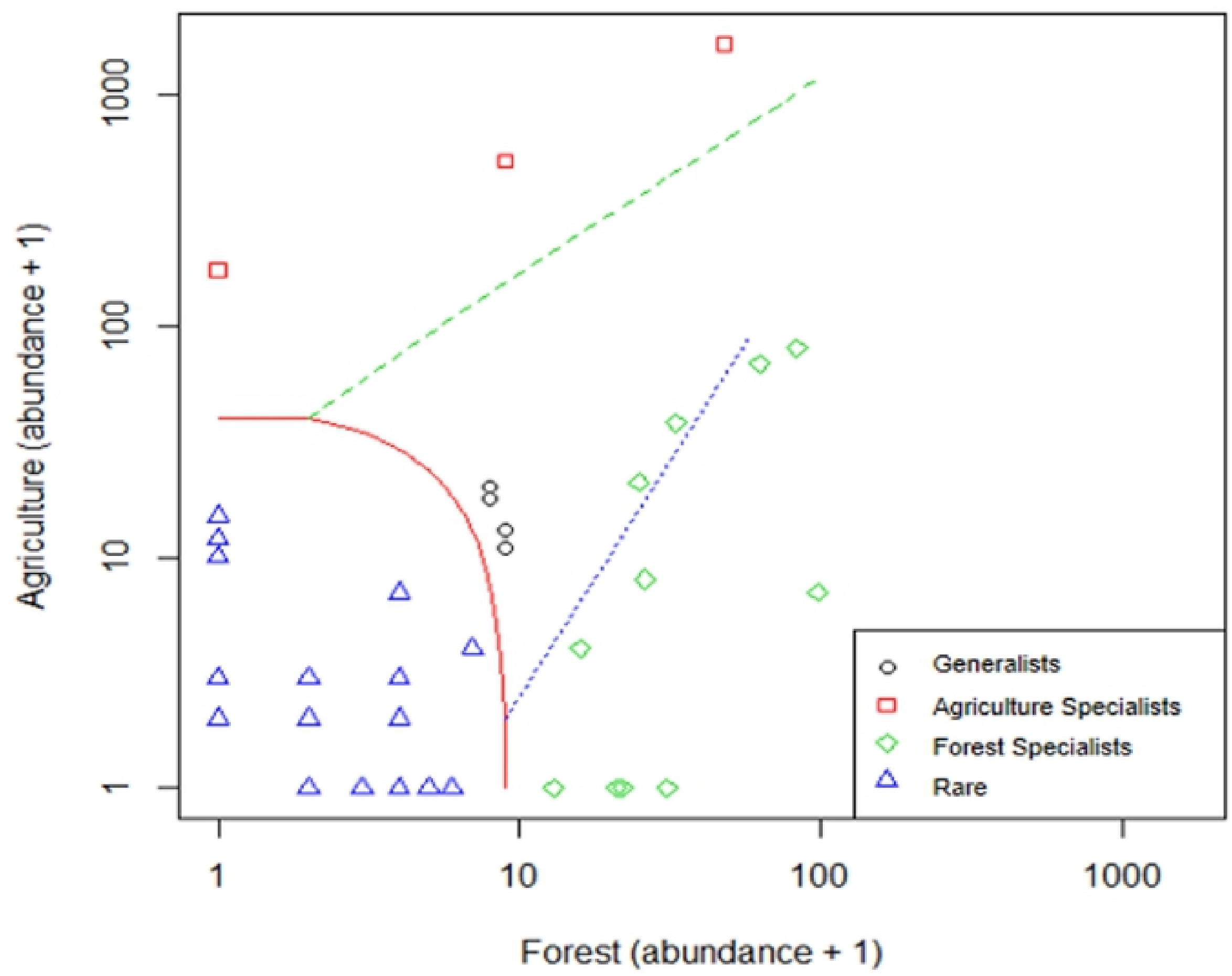

Figure 


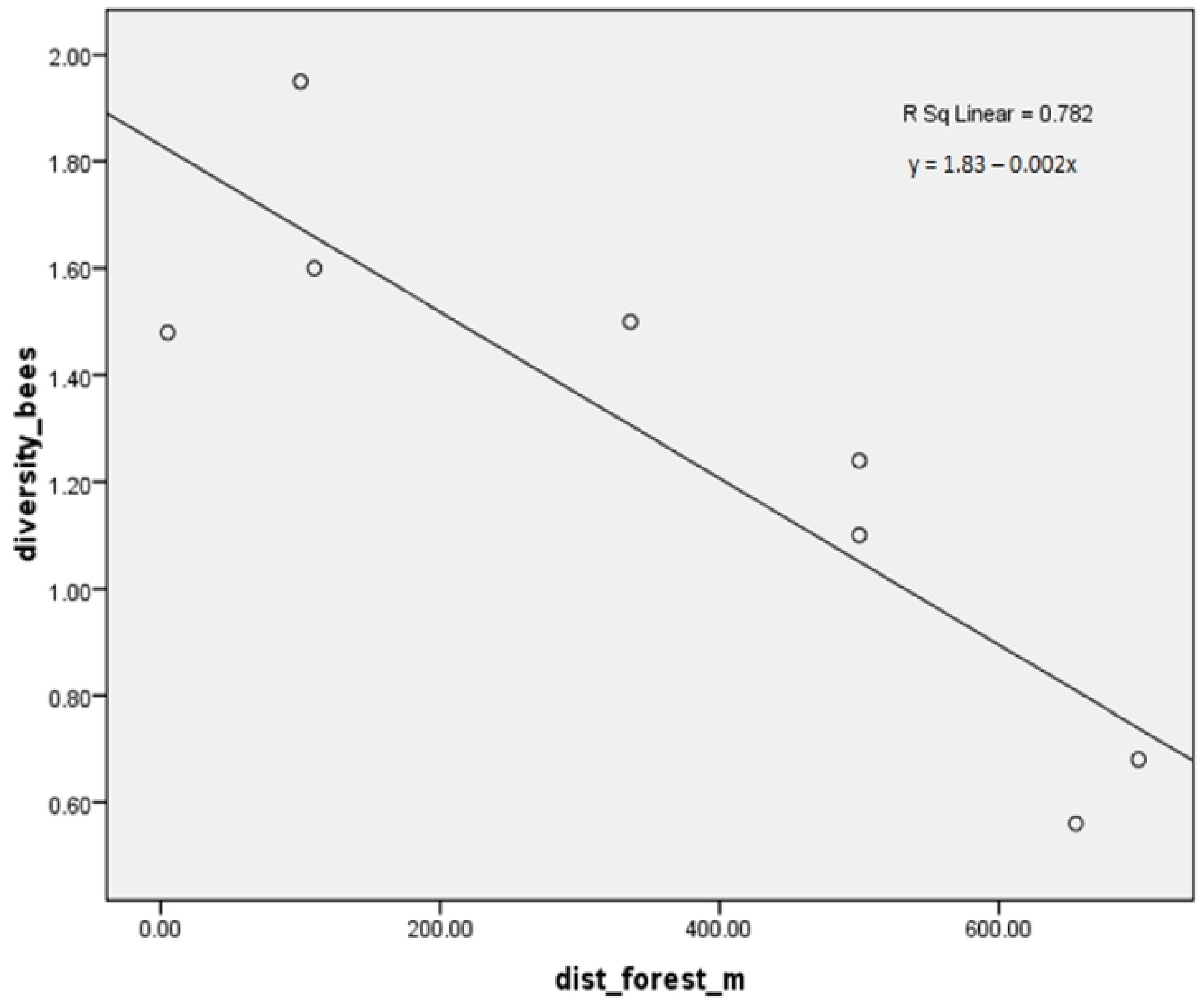

Figure 